\title{
Retroactivity of extended confiscation and the EU minimum standard
}

\section{Opinion}

Directive 2014/42/EU of the European Parliament and of the Council of 3 April 2014 on the freezing and confiscation of instrumentalities and proceeds of crime in the European Union $(E U)^{1}$ introduced one minimum standard for extended confiscation. ${ }^{2}$ Previously, the extended powers of confiscation could be shaped according to a set of variants specified in the Council Framework Decision 2005/212/JHA of 24 February 2005 on Confiscation of Crime-Related Proceeds, Instrumentalities and Property. ${ }^{3}$ Extended confiscation is not based on plain proof (proof beyond a reasonable doubt in common law) relevant to the criminal process. Thus, the link between property and crime is loosened. Despite the difficulties in proving the criminal origin of assets, this type of confiscation reflects the principle of unprofitability of crime. ${ }^{4}$ The evidentiary problems in ordering extended confiscation are solved by using substitutes for plain proof. The first option is to rule on the basis of the discretion of the court limited by the circumstances set out in the law (e.g. disproportionality of property to officially declared income or size of business activity, involvement in organized crime). The court then, on the basis of certain facts, alleges the illegality of the origin of property, but this is not yet a legal presumption (lat. praesumptio iuris tantum). The second solution is to use the rebuttable legal presumption as to the origin of illicit assets. Both solutions do not exclude the proof to the contrary by demonstrating the legal origin of the property, as well as the transfer of its burden from the prosecutor to the person against whom the extended confiscation is applied. The directive 2014/42/EU to extend the scope of confiscation uses the court's discretion limited by the circumstances of the case, facts and evidence, which include, in particular, the disproportionality of the value of the property to the lawful income of the convicted person (Article 5). ${ }^{5}$ The court may rule on the basis of a balance of probabilities or a reasonable presumption. An important issue is that the EU Member States could also determine in their domestic legal orders, a requirement for a certain period of time during which the property could be deemed to have originated

${ }^{1}$ OJ L 127, 29.04.2014, p. 39.

${ }^{2}$ Evaluation report on national law is to be presented by the European Commission by 4.10 .2019 .

${ }^{3}$ OJ L 68, 15.03.2005, p. 49. See M. Fazekas, E. Nanopoulos, The Effectiveness of EU Law: Insights from the EU Legal Framework on Asset Confiscation, European Journal of Crime, Criminal Law and Criminal Justice 24 (2016), pp. $42-43$.

${ }^{4}$ On the justification of confiscation see: P. Alldridge, Money Laundering Law. Forfeiture, Confiscation, Civil Recovery, Criminal Laundering and Taxation of the Proceeds of Crime, Hart Publishing, Oxford - Portland Oregon (2003), pp. 45-62; J. Boucht, Extended Confiscation and the Proposed Directive on Freezing and Confiscation of Criminal Proceeds in the EU: On Striking a Balance between Efficiency, Fairness and Legal Certainty, European Journal of Crime, Criminal Law and Criminal Justice 21 (2013), pp. 128-129; M. Agheniței, Confiscation of Criminal Proceeds in the European Union Law, AGORA International Journal of Juridical Sciences 3 (2013), p. 2.

${ }^{5}$ The Framework Decision 2005/212/JHA also referred to the court's recognition in each of the variants of extended confiscation.
Volume 2 Issue 3 - 2018

\author{
Ariadna $\mathrm{H}$ Ochnio \\ Department of Criminal Law, Institute of Law Studies, Polish \\ Academy of Sciences, Poland
}

Correspondence: Ariadna H Ochnio, Department of Criminal Law, Institute of Law Studies, Polish Academy of Sciences, Warsaw, Poland, Email ariadnaochnio@wp.pl

Received: January 29, 2018 | Published: May 23, 2018

from criminal conduct (recital 21 of the preamble). Judicial discretion is undoubtedly a more flexible solution than a strict legal presumption and may be better suited to the needs of an individual decision. On the other hand, a rebuttable legal presumption is a significant facilitation of evidence for the court that can make the recovery of assets from crime real.

The problem is to reconcile the rights of the defence with the "retroactive effect" of extended confiscation resulting from the application of the legal presumption. The EU jurisdictions in their national legislation have adopted a variety of solutions to the "retroactive" scope of confiscation, for example by reference to the time prior to the date of committing a prohibited act or prior to the initiation of the proceedings related to such an act. The latter seems more rational, as the proceedings may be significantly delayed in relation to the period of undertaking criminal activity. Because of the insurmountable difficulties in rebutting the legal presumption with the use of the contrary evidence, resulting from the passage of time, we should reconsider whether the EU minimum standard of extended confiscation should also cover the maximum scope of its retroactivity. Otherwise, the method of regulating extended confiscation in domestic laws may make the right to defence fictitious and inconsistent with the principles of a fair criminal trial. Taking these factors into consideration leads to the conclusion that the EU minimum standard of extended confiscation needs to be improved in the area of defence rights. The 'retroactive effect' of extended confiscation should be limited at the EU level by an appropriate method of defining its scope. First of all, Member States should not determine the scope of such confiscation by referring to assets acquired before the date of committing a prohibited act, but to those obtained before the day of initiation of proceedings related to a prohibited act. The maximum retrograde period should be clearly defined in the directive and the EU countries should be obliged to adapt it to the length of the period of storage of business and tax documentation required by national law. Finally, if the extended confiscation covers assets obtained in the period before the opening of proceedings related to a prohibited act and if even a part of this period fell within the period prior to committing a prohibited act, in this respect the ruling should be based on the court's recognition, and not on the legal presumption. 